\title{
ВПЛИВ ІНСУЛІНОРЕЗИСТЕНТНОСТІ НА ПЕРЕБІГ ТА НЕЙРОФІЗІОЛОГІЧНІ ПОКАЗНИКИ ХВОРИХ НА ПОЛІНЕЙРОПАТІЮ
}

Національна медична академія післядипломної освіти імені П.Л. Шупика, м. Київ

\begin{abstract}
Резюме. Метаболічний синдром (МC) є актуальною міждисциплінарною проблемою сучасної медицини. Периферична нервова система (ПНС), як одна 3 найбільш уразливих систем, досить часто привносить симптоматику свого ураження в клінічну картину МС. Метою дослідження було вивчення впливу інсулінорезистентності на перебіг та нейрофізіологічні показники хворих на полінейропатію та виявлення серед них визначальних для диференціації між полінейропатію, асоційованою з інсулінорезистентністю чи з інсулінодефіцитом.

Матеріал і методи. У поперечне дослідження включені 35 пацієнтів 3 клінічними ознаками дистальної симетричної полінейропатії віком від 20 до 60 років, що були розподілені на дві групи. Перша група складалася 323 пацієнтів (13 чоловіків та 10 жінок) 3 метаболічним синдромом. Друга група складалася 312 пацієнтів (4 чоловіків та 8 жінок) 3 діагностованим цукровим діабетом 1-го типу. Усім пацієнтам проведено клініко-неврологічне дослідження та стимуляційна електроміографія (ЕМГ), а також визначався глікований гемоглобін, інсулін, глюкоза натщесерце, та індекс HОМА-IP. Отриманий матеріал був оброблений методами описової та непараметричної статистики.
\end{abstract}

Вступ. Метаболічний синдром (МС) є актуальною міждисциплінарною проблемою сучасної медицини. Це пов'язано з системністю патологічних змін як дисметаболічних, так і дисциркуляторних, що супроводжують цей патологічний стан. Периферична нервова система (ПНС) як одна 3 найбільш уразливих систем, досить часто привносить симптоматику свого ураження в клінічну картину МС. Як стан, що супроводжується інсулінорезистентністю (IP) та гіперпродукцією інсуліну, іншими дисметаболічними наслідками МС призводить до ендотеліальної дисфункції, ригідності та жорсткості артерій, порушує вазодилатацію, зумовлену оксидом азоту, асоціюється з гіперкоагуляцією, збільшує мембранну плинність, активує симпато-адреналову систему, стимулює продукцію прозапальних цитокінів $[1,2]$. Хоча механізми негативного впливу надлишку інсуліну та IP вивчені не повністю, але не викликає сумніву, що одною 3 мішеней його може бути ПНС. За результатами проведених експериментальних досліджень на щурах та мишах $[3,4]$ доведено, що інсулінорезистентність призводить, у першу чергу, до порушень із боку ПНС у вигляді зниження швидкості проведення по нерву та чутливих порушень на відміну від інсулінодефіцитного стану, де поряд з ураженням ПНС може переважати ураження з боку ЦНС, та ці відмінності можуть формувати фенотип нейропатії [3]. При дослідженні стану щурів із модульованою IP виявлено за допомогою електронної мікроскопії

(C) В.В. Оржешковський, 2016

112
Результати дослідження та їх обговорення. Отримані дані свідчили, що в пацієнтів 1 групи на ступінь виразності клінічних проявів полінейропатії впливають індекс НОМА-ІР та рівень глікованого гемоглобіну. На ознаки розповсюдження патологічного процесу на проксимальні відділи ПНС впливали індекс HOMA-IP та вік пацієнтів, на ознаки демієлінізуючого процесу НОМА-IP та IMT, рівень глікованого гемоглобіну, рівень глюкози натщесерце. При порівнянні електроміографічних показників обох груп виявлений більш виражений наявний демієлінізуючий процес у пацієнтів 2-ї групи, та більшу уразливість ліктьового нерва $з$ ознаками як його аксональної дегенерації $з$ можливим функціональним блоком проведення.

Висновки. Інсулінорезистентність впливає на клінічний перебіг та нейрон-фізіологічні показники у хворих на полінейропатію. Клінічні прояви пов'язані 3 індексом НОМА-IP та рівнем глікованого гемоглобіну. Електроміографічні показники пов'язані з віком, індекс маси тіла, індексом НОМА-ІР, рівнем глікованого гемоглобіну та глюкози натщесерце.

Ключові слова: інсулінорезистентність, метаболічний синдром, полінейропатія, стимуляційна електроміографія, цукровий діабет.

ураження переважно добре мієлінізованих волокон із мінімальними змінами з боку слабо- та немієлінізованих волокон, а також формування больового невропатичного синдрому, що підсилювався на тлі дієти з високим вмістом солі [4]. Всі ці експериментальні дані свідчать про відміну клінічної картини, патогенетичних механізмів уражень ПНС при IP та інсулінодефіциті.

Мета дослідження. Вивчити вплив інсулінорезистентності на перебіг та нейрофізіологічні показники хворих на полінейропатію, виявлення серед них визначальних для диференціації між полінейропатію, асоційованою з інсулінорезистентністю чи з інсулінодефіцитом.

Матеріал і методи. У поперечне дослідження включені 35 пацієнтів із клінічними ознаками дистальної симетричної полінейропатії віком від 20 до 60 років, що були розподілені на дві групи. Критеріями включення до першої групи була наявність діагностичних критеріїв метаболічного синдрому Міжнародної діабетичної федерації (IDF, 2006) [1], критеріїв виключення - наявність інших захворювань або етіологічних факторів, що можуть зумовити полінейропатію. Перша група складалася з 23 пацієнтів (13 чоловіків та 10 жінок), середній вік становив (M $\pm \mathrm{STD})$ $48,4 \pm 9,86$ року. Критеріями включення до другої групи був наявний та діагностований цукровий діабет 1-го типу, а критерієм виключення - наявність інших захворювань або етіологічних факторів, що можуть зумовити полінейропатію. Друга 
група складалася з 12 пацієнтів (4 чоловіків та 8 жінок) середній вік становив $(\mathrm{M} \pm \mathrm{STD}) 35,7 \pm 9,16$ року. Усім пацієнтам проведено клініконеврологічне дослідження з визначенням індексу маси тіла (IMT), балів за шкалою TCNSS (Toronto Clinical Neuropathy Scoring System), нейропатичного дисфункціонального рахунку (НДР), а також стимуляційна електроміографія (ЕМГ) на апараті "Нейрон-Спектр-4/ВПМ" (Російська Федерація). Електроміографічне дослідження включало визначення амплітуди М-відповіді, резидуальної латентності, наявності блоків проведення, пізньої відповіді - F-хвилі, швидкості розповсюдження збудження по моторних (ШРЗм по n.tibialis, n.peroneus, n.medialis, n.ulnaris) та сенсорних нервах (ШРЗс по n.saphenus, n.suralis, n.medialis, n.ulnaris) нижніх та верхніх кінцівок. У першій групі визначався глікований гемоглобін, інсулін, глюкоза натщесерце, та індекс НОМА-IP. Отриманий матеріал оброблений методами описової статистики з визначенням М - вибіркового середнього, STD - вибіркового стандартного відхилення та непараметричної статистики $\chi^{2}$, кореляційного аналізу з визначенням рангового коефіцієнта кореляції Спірмена $\mathrm{r}_{\mathrm{s}}$. Критичний рівень значимості при перевірці статистичних гіпотез у даному дослідженні приймали рівним 0,05, p досягнутий рівень значимості. Для обробки використовувався пакет "Statistica 10".

Результати дослідження та їх обговорення. У результаті проведеного дослідження отримані наступні дані. За даними клінічного обстеження 3 використанням шкал TCNSS та НДР в обох групах спостерігалася наявна легка або помірно виражена полінейропатія. У 1-й групі середній бал (M \pm STD) за шкалою TCNSS становив $9,1 \pm 1,29$, за шкалою НДР - 10,8 $\pm 2,47$ та IMT 30,7 $\pm 3,23$, у 2-ій групі - 10,2 $\pm 0,72,12,2 \pm 1,53$ та $18,9 \pm 0,58$ відповідно. За даними електроміографічного дослідження в обох групах були наявні ознаки ураження як моторних, так і сенсорних волокон. У 1-ій групі середній показник $(\mathrm{M} \pm \mathrm{STD})$ індексу HOMA-IP був 5,6 $\pm 1,81$, глікованого гемоглобіну $6,2 \pm 0,74 \%$ та глюкози натщесерце - 6,3 $\pm 0,98$ ммоль/л.

За даними кореляційного аналізу, у 1-й групі виявлений кореляційний зв'язок індексу НОМА$\mathrm{IP}$, прямий із глікованим гемоглобіном $\left(\mathrm{r}_{\mathrm{s}}=0,67\right)$, глюкозою натщесерце $\left(\mathrm{r}_{\mathrm{s}}=0,48\right)$, 3 показниками за шкалами TCNSS $\left(r_{s}=0,59\right)$ та НДР $\left(r_{s}=0,38\right)$, зменшенням швидкості по проксимальних відділах ПНС за даними F-хвилі $\left(\mathrm{r}_{\mathrm{s}}=0,48\right)$, наявністю блоків проведення по моторних волокнах n.peroneus $\left(\mathrm{r}_{\mathrm{s}}=0,73\right)$. Вік пацієнтів корелював зі зменшенням швидкості по проксимальних відділах ПНС за даними F-хвилі $\left(\mathrm{r}_{\mathrm{s}}=0,64\right)$, та мав оборотний зв'язок 3 ШРЗc n.ulnaris $\left(\mathrm{r}_{\mathrm{s}}=-0,73\right)$. IMT мав прямий кореляційний зв'язок із глікованим гемоглобіном $\left(\mathrm{r}_{\mathrm{s}}=0,66\right)$, глюкозою натщесерце $\left(\mathrm{r}_{\mathrm{s}}=0,65\right)$, наявністю блоків проведення по моторних волокнах n.peroneus $\left(\mathrm{r}_{\mathrm{s}}=0,58\right)$. Рівень глікованого гемоглобіну корелював 3 рівнем глюкози $\left(\mathrm{r}_{\mathrm{s}}=0,57\right)$, 3 по- казниками за шкалами TCNSS $\left(\mathrm{r}_{\mathrm{s}}=0,56\right)$ та НДР $\left(\mathrm{r}_{\mathrm{s}}=0,44\right)$, наявністю блоків проведення по моторних волокнах n.peroneus $\left(\mathrm{r}_{\mathrm{s}}=0,8\right)$ та n.medialis $\left(r_{s}=0,62\right)$, та мав оборотний зв'язок із ШРЗс n.ulnaris $\left(\mathrm{r}_{\mathrm{s}}=-0,7\right)$. Рівень глюкози натщесерце мав прямий кореляційний зв'язок із наявністю блоків проведення по моторних волокнах n.medialis $\left(\mathrm{r}_{\mathrm{s}}=0,61\right)$ та оборотний із ШРЗм по n.tibialis $\left(\mathrm{r}_{\mathrm{s}}=\right.$ $0,72)$, n.peroneus $\left(r_{s}=-0,61\right)$ та n.ulnaris $\left(r_{s}=-0,56\right)$. Таким чином, отримані дані свідчили, що в пацієнтів 1-ї групи на ступінь виразності клінічних проявів полінейропатії за шкалами TCNSS та НДР впливають індекс НОМА-ІР та рівень глікованого гемоглобіну, індекс НОМА-ІР, глікований гемоглобін та глюкоза натщесерце мають кореляційний взаємозв'зок, ІМТ впливає на рівень глікованого гемоглобіну та глюкози натщесерце. 3 нейрофізіологічними показниками спостерігалась наступна закономірність. На ознаки розповсюдження патологічного процесу на проксимальні відділи ПНС впливали індекс НОМА-IP та вік пацієнтів, на ознаки демієлінізуючого процесу у вигляді наявності блоків проведення по моторних волокнах n.peroneus впливали індекс HOMA-IP та IMT, n.peroneus та n.medialis рівень глікованого гемоглобіну, n.medialis рівень глюкози натщесерце. Оборотний зв'язок зі ШРЗм по n.tibialis, n.peroneus та n.ulnaris, що також свідчить про негативний вплив на демієлінізацію, мав рівень глюкози натщесерце. Також оборотний зв'язок із ШРЗc n.ulnaris, що також відображає демієлінізацію чутливих волокон, мали вік пацієнтів та рівень глікованого гемоглобіну.

При порівнянні електроміографічних показників обох груп були виявлені наступні достовірні відмінності. У 2-й групі частіше реєструвалися зменшення нижче нормальних показників ШРЗм по n.medialis ( $\chi^{2} 3$ поправкою Йєтса 3,85 ; $\mathrm{p}=0,0497$ ) по n.tibialis $\left(\chi^{2}(\mathrm{df}=1) 4,06 ; \mathrm{p}=0,044\right)$ по n.peroneus $\left(\chi^{2}(\mathrm{df}=1) 5,11 ; \mathrm{p}=0,024\right)$, як ознаки більш вираженого демієлінізуючого процесу в цих нервах. У 1-й групі частіше реєструвалися зменшення нижче нормальних показників амплітуди М-відповіді $\left(\chi^{2}(\mathrm{df}=1) 4,23 ; \mathrm{p}=0,040\right)$ та наявність блоків проведення по моторних волокнах $\left(\chi^{2}\right.$ $(\mathrm{df}=1) 6,32 ; \mathrm{p}=0,012)$ n.ulnaris в основному за рахунок можливого ураження цього нерва у вузькому каналі кубітального каналу. Виявлені відмінності свідчать про більш виражений наявний демієлінізуючий процес у пацієнтів 2-ї групи, та більшу уразливість ліктьового нерва 3 ознаками як його аксональної дегенерації, так і можливого дисметаболічного та дисциркуляторного процесу 3 можливим функціональним блоком проведення при несприятливих умовах при проходженні його у вузькому каналі.

\section{Висновки}

1. Інсулінорезистентність впливає на клінічний перебіг полінейропатії та нейрон-фізіологічні показники хворих. Клінічні прояви пов'зані 3 індексом НОМА-IP та рівнем глікованого гемоглобіну. 
2. Електроміографічні показники пов'язані 3 віком, індексом маси тіла, індексом НОМА-IP, рівнем глікованого гемоглобіну та глюкози натщесерце. Індекс НОМА-IP та вік впливають на ознаки розповсюдження патологічного процесу на проксимальні відділи периферичної нервової системи, індекс маси тіла, індекс НОМА-IP, piвень глікованого гемоглобіну та глюкози натщесерце пов'язані з проявами демієлінізації моторних волокон нервів нижніх та верхніх кінцівок, а рівень глікованого гемоглобіну впливає також на демієлінацію чутливих волокон n.ulnaris.

3. Розпізнавальними рисами, що відрізняють полінейропатію з інсулінорезистентістю та інсулінодефіцитом можуть бути більш виражена демієлінізація зі зниженням швидкості розповсюдження збудження по моторних нервах (по n.medialis, n.tibialis та n.peroneus) при інсулінодефіциті та більша уразливість ліктьового нерва 3 ознаками, як його аксональної дегенерації та функціональним блоком проведення за несприятливих умовах при проходженні його в вузькому каналі при інсулінорезистентності.

Перспективи подальших досліджень. Перспективним $є$ продовження вивчення негативного впливу інших факторів, що супроводжують інсулінорезистентність, таких, як рівень прозапальних цитокінів та інших показників на клінічні та нейрофізіологічні прояви інсулінрезистентноасоційованих полінейропатій.

\section{Література}

1. Каминский А.В. Сахарный диабет и ожирение: клиническое руководство по диагностике и лечению / А.В. Каминский, А.Н. Коваленко. - К.: Салютис, 2010. $-255 \mathrm{c}$.

2. Сергиенко В.А. Резистентность к инсулину и ригидность артерий у больных сахарным диабетом 2-го типа с кардиоваскулярной вегетативной нейропатией / В.А. Сергиенко // Ж. неврол. и психиатрии им. С.С. Корсакова. - 2014. - Т. 114 (4). - С. 11-15.

3. Anderson N.J. Role of insulin signaling impairment, adiponectin and dyslipidemia in peripheral and central neuropathy in mice / N.J. Anderson, M.R. King, L. Delbruck // Dis. Model Mech. - 2014. - Jun. - Vol. 7 (6). P. 625-633.

4. Fang Xie. High Energy Diets-Induced Metabolic and Prediabetic Painful Polyneuropathy in Rats / Fang Xie / PLoS One. - 2013. - № 8 (2). - P. 57427.

\section{ВЛИЯНИЕ ИНСУЛИНОРЕЗИСТЕНТНОСТИ НА ТЕЧЕНИЕ И НЕЙРОФИЗИОЛОГИЧЕСКИЕ ПОКАЗАТЕЛИ БОЛЬНЫХ С ПОЛИНЕЙРОПАТИЕЙ}

\section{В.В.Оржешковский}

Резюме. Метаболический синдром (МС) - актуальная междисциплинарная проблема современной медицины. Периферическая нервная система (ПНС), как одна из наиболее уязвимых систем, довольно часто привносит симптоматику своего поражения в клиническую картину МС.

Целью исследования было изучение влияния инсулинорезистентности на течение и нейрофизиологические показатели больных с полинейропатией и выявление среди них определяющих для дифференциации между полинейропатией, ассоциированной с инсулинорезистентностью или с инсулинодефицитом.

Материал и методы. В поперечное исследование были включены 35 пациентов с клиническими признаками дистальной симметричной полинейропатии возрастом от 20 до 60 лет, которые были разпределены на две группы. Первая группа состояла из 23 пациентов (13 мужчин и 10 женщин) с метаболическим синдромом. Вторая группа состояла из 12 пациентов (4 мужчин и 8 женщин) с диагностированным сахарным диабетом 1-го типа. Всем пациентам было проведено клинико-неврологическое исследование и стимуляционная электромиография (ЭМГ), а также определялся гликированный гемоглобин, инсулин, глюкоза натощак, и индекс НОМА-ИР. Полученный материал был обработан методами описательной и непараметрической статистики.

Результаты исследования и их обсуждение. Полученные данные свидетельствовали, что у пациентов 1-ой группы на степень выраженности клинических проявлений полинейропатии влияют индекс НОМА-ИР и уровень гликированного гемоглобина, На признаки распространения патологического процесса на проксимальные отделы ПНС влияли индекс НОМА-ИР и возраст пациентов, на признаки демиелинизирующего процесса НОМА-ИР и ИМТ, уровень гликированного гемоглобина, уровень глюкозы натощак. При сравнении электромиографических показателей обеих групп выявлен более выраженный имеющийся демиелинизирующий процесс у пациентов 2-ой группы, и большая уязвимость локтевого нерва с признаками его аксональной дегенерации с возможным функциональным блоком проведения.

Выводы. Инсулинорезистентность влияет на клинический течение и нейронфизиологические показатели у больных с полинейропатией. Клинические проявления связаны с индексом НОМА-ИР и уровнем гликированого гемоглобина. Электромиографические показатели связаны с возрастом, ИМТ, индексом НОМА-ИР, уровнем гликированного гемоглобина и глюкозы натощак.

Ключевые слова: инсулинорезистентность, метаболический синдром, полинейропатия, стимуляционная электромиография, сахарный диабет.

\section{EFFECTS OF INSULIN RESISTANCE TO CURRENT AND NEUROPHYSIOLOGICAL PARAMETERS OF PATIENTS WITH POLYNEUROPATHY}

\section{V.V. Orzheshkovskyi}

Abstract. Metabolic syndrome (MS) is a topical interdisciplinary problem of modern medicine. The peripheral nervous system (PNS) as one of the most vulnerable systems often brings symptoms of its damage in the clinical picture of MS. 
The aim of the study was to investigate the effect of insulin resistance on the current and neuropsychological performance in patients with polyneuropathy and identify polyneuropathy associated with insulin resistance or with insulin deficit. Material and methods. The cross-sectional study included 35 patients with clinical signs of distal symmetric polyneuropathy aged from 20 to 60 years, who were divided into 2 groups. The first group consisted of 23 patients (13 men and 10 women) with the metabolic syndrome. The second group consisted of 12 patients ( 4 men and 8 women) diagnosed with type 1 diabetes. All patients underwent clinical and neurological examination and stimulation electromyography (EMG), and determined $\mathrm{HbAlc}$, insulin, fasting glucose and HOMA-IR index. The resulting material was treated with the methods of descriptive and non-parametric statistics. Results and discussion. The data showed that patients of group 1 on the severity of clinical manifestations of polyneuropathy affecting HOMA-IR index and the level of HbAlc, on signs of pathological process in the proximal parts of the PNS influenced index HOMA-IR and age of patients for signs of demyelinating process HOMAIR and BMI, level of $\mathrm{HbAlc}$, fasting glucose levels. When comparing electromyographic parameters of both groups, we revealed tha a more pronounced demyelinating process is available in 2 groups of patients, and greater vulnerability of the ulnar nerve with signs of its axonal degeneration with the possibility of a functional unit. Conclusions. Insulin resistance affects the clinical course and neuro-physiological parameters in patients with polyneuropathy. Clinical manifestations are associated with HOMA-IR index and the level of HbAlc. The electromyographic indicators are associated with age, BMI, HOMA-IR index, level of HbAlc and fasting glucose.

Key words: insulin resistance, metabolic syndrome, polyneuropathy, stimulation electromyography, diabetes.

Shupyk National Medical Academy of Postgraduate Education (Kyiv)

Рецензент - проф. Н.В. Пашковська

Buk. Med. Herald. - 2016. - Vol. 20, № 2 (78). - P. 112-115

Надійшла до редакції 05.04.2016 року

(C) В.В. Оржешковський, 2016 